\title{
Analysis of electrolytic process parameters based on orthogonal test method
}

\author{
Ning Sun ${ }^{a}$,Daolin Jiang ${ }^{b}$ \\ School of Mechanical and Electrical Engineering,Guilin University of Electronic Technology,Gulin \\ 541004,China \\ axiangjiang1949@163.com, bsunning@guet.edu.cn
}

Keywords: Orthogonal test, factors and levels, range analysis, variance analysis.

\begin{abstract}
In the process of electrolysis of rare earth metals, there are many factors that affect the final electrolytic production. These process parameters are usually determined by the workers in the factory according to their own experience, there is no statistical analysis of the scientific data to the final establishment. This chapter will design a set of multi factor and multi level orthogonal experiment through the actual production data of a factory in Hezhou, In order to study the influence of factors on the production results.
\end{abstract}

\section{Introduction}

In actual production practice, there are many factors that affect the experimental results. We often have to do a lot of factor tests, How to arrange the multi factor experiment is a question which is worth studying. If we test the level of each factor, In a number of factors, the number of trials to do is amazing.

Figure 1 as an example

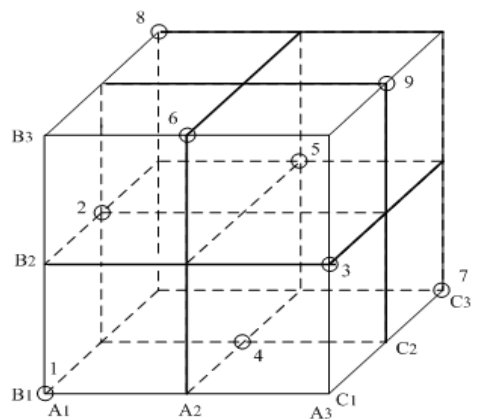

Figure 1.Test point distribution of two experimental design methods

Figure 1 represents a test design for three factors and three levels, Assuming that three vertical $\mathrm{X}$ axis, Y axis, $\mathrm{Z}$ axis of the three planes were the representative factors of $\mathrm{A}$, factor $\mathrm{B}$, factor $\mathrm{C}$ three levels. The intersection of each three lines represents a combination of three factors, 27 nodes in a cube represent the 27 test. This kind of experiment is called comprehensive test method. But with the use of orthogonal test is only 9 times the test, Specifically speaking, From any direction of the cube is divided into 3 levels, each plane contains 9 intersections, there are exactly 3 test points that are arranged by the orthogonal table. The 9 test points are uniformly distributed in the three-dimensional space. The orthogonal test method is aimed at the above situation, In reducing the number of tests to complete a number of parameters optimization, it is a kind of design method of multi factor and multi level by orthogonal table, in place of all the tests to reflect the overall situation.

\section{Analysis method}

\subsection{Range analysis}

Range analysis method, also known as visual analysis method. It has the advantages of simple calculation, easy to understand, and so on, it is the most commonly used method for the analysis of the results of orthogonal test. Range analysis method is called as R method. Let $\mathrm{T}$ be the sum of all 
the index values, $\quad T=\sum_{i=1}^{n} \mathrm{x}_{i}, \mathrm{~T}$ indicates that the test parameters and the corresponding I $(\mathrm{i}=1,2,3,4)$ on the level of any column. $t_{i}=\frac{T_{i}}{r}, \mathrm{r}$ indicates the number of times the level of each column appears. $\mathrm{R}$ is called range, $\mathrm{R}=\max (\mathrm{T} 1, \mathrm{~T} 2, \mathrm{~T} 3, \mathrm{~T} 4)-\min (\mathrm{T} 1, \mathrm{~T} 2, \mathrm{~T} 3, \mathrm{~T} 4)$ or $\mathrm{R}=\max （ \mathrm{t} 1, \mathrm{t} 2, \mathrm{t} 3, \mathrm{t} 4)$ -min $(\mathrm{t} 1, \mathrm{t} 2, \mathrm{t} 3, \mathrm{t} 4)$ 。The range analysis method includes two steps: Calculation and Judgment.

\subsection{Variance analysis}

The key of variance analysis is the decomposition of deviation square sum.

Total deviation square and total degree of freedom:

$$
S S E=\sum_{k} S S_{j}, f_{e}=\sum_{k} f_{j}
$$

Sum of squares of deviations in each column and degree of freedom:

$$
S S_{\mathrm{j}}=\mathrm{r} \sum_{\mathrm{i}=1}^{\mathrm{m}}\left(\mathrm{t}_{\mathrm{i}}-\bar{X}\right)^{2}=\frac{1}{\mathrm{r}} \sum_{i=1}^{\mathrm{m}} T_{\mathrm{i}}^{2}-\frac{T^{2}}{\mathrm{n}}, \quad(\mathrm{j}=1,2, \ldots, \mathrm{k}), \mathrm{f}_{\mathrm{j}}=m-1
$$

Here, $\mathrm{r}=\mathrm{n} / \mathrm{m}$ 。

Table 2.1 analysis of variance table

\begin{tabular}{|c|c|c|c|c|c|c|}
\hline $\begin{array}{c}\text { Source of } \\
\text { variance }\end{array}$ & $\begin{array}{c}\text { Sum of } \\
\text { squares }\end{array}$ & freedom & $\begin{array}{c}\text { Mean } \\
\text { square } \\
\text { deviation }\end{array}$ & Value of F & Fa & Significant \\
\hline factor 1 & SS1 & f1 & $\begin{array}{c}\text { MS1= } \\
\text { SS1/ f1 }\end{array}$ & F1=MS1/MSE & & \\
\hline factor 2 & SS2 & f2 & $\begin{array}{c}\text { MS2= } \\
\text { SS2/ f2 }\end{array}$ & F2=MS2/MSE & & \\
\hline$\ldots$ & $\ldots$ & $\ldots$ & $\ldots$ & $\ldots$ & & \\
\hline error & SSE & Fe & $\begin{array}{c}\text { MSE }= \\
\text { SSE/ fe }\end{array}$ & & & \\
\hline the sum & SST & n-1 & & & & \\
\hline
\end{tabular}

For factor $\mathrm{j}$, given a significant level of a, Check list for value of Fa.if $\mathrm{Fj}>\mathrm{Fa}$, We believe that the impact of $\mathrm{J}$ on the test results is significant.

\subsection{Orthogonal test analysis}

Based on the reference of domestic and foreign literature and the actual production situation in the factory practice, The test selects the main influencing factors: electrolytic voltage, electrolytic temperature, reaction time, feeding frequency, polar distance. Each group of factors to take four process level. Detailed factor levels are classified as shown in Table 2.2

Table 2.2

\begin{tabular}{cccccc}
\hline Factor level & $\begin{array}{c}\mathrm{A} \\
\text { electrolytic } \\
\text { voltage } \\
(\mathrm{V})\end{array}$ & $\begin{array}{c}\mathrm{B} \\
\text { electrolytic } \\
\text { temperature } \\
\left({ }^{0} \mathrm{C}\right)\end{array}$ & $\begin{array}{c}\mathrm{C} \\
\text { reaction } \\
\text { time } \\
(\mathrm{min})\end{array}$ & $\begin{array}{c}\mathrm{D} \\
\text { polar } \\
\text { distance } \\
(\mathrm{mm})\end{array}$ & $\begin{array}{c}\mathrm{E} \\
\text { feeding } \\
\text { frequency } \\
(\mathrm{min})\end{array}$ \\
\hline 1 & 9.0 & 950 & 30 & 8.5 & 5 \\
2 & 9.5 & 1000 & 40 & 9.5 & 10 \\
3 & 10.0 & 1050 & 50 & 10.5 & 15 \\
4 & 10.5 & 1100 & 60 & 11.5 & 20 \\
\hline
\end{tabular}

According to the table 2.2 factors of the level of the division, we decided to use the five factor four level orthogonal test matrix to design L16 $\left(4^{5}\right)$ orthogonal table. Results of orthogonal test are shown in Table 2.3 
Table 2.3

\begin{tabular}{ccccccc}
\hline $\begin{array}{c}\text { Test } \\
\text { number }\end{array}$ & $\begin{array}{c}\text { electrolytic } \\
\text { voltage } \\
(\mathrm{V})\end{array}$ & $\begin{array}{c}\text { electrolytic } \\
\text { temperature } \\
(0 \mathrm{C})\end{array}$ & $\begin{array}{c}\text { reaction } \\
\text { time } \\
(\mathrm{min})\end{array}$ & $\begin{array}{c}\text { polar } \\
\text { distance } \\
(\mathrm{mm})\end{array}$ & $\begin{array}{c}\text { feeding } \\
\text { frequency } \\
(\text { min })\end{array}$ & $\begin{array}{c}\text { Qualified } \\
\text { rate } \\
(\%)\end{array}$ \\
\hline 1 & 9.0 & 950 & 30 & 85 & 5 & 78.6 \\
2 & 9.0 & 1000 & 40 & 95 & 10 & 86.7 \\
3 & 9.0 & 1050 & 50 & 105 & 15 & 91.8 \\
4 & 9.0 & 1100 & 60 & 115 & 20 & 82.1 \\
5 & 9.5 & 950 & 40 & 105 & 20 & 80.3 \\
6 & 9.5 & 1000 & 30 & 115 & 15 & 83.6 \\
7 & 9.5 & 1050 & 60 & 85 & 10 & 98.1 \\
8 & 9.5 & 1100 & 50 & 95 & 5 & 92.2 \\
9 & 10.0 & 950 & 50 & 115 & 10 & 79.3 \\
10 & 10.0 & 1000 & 60 & 105 & 5 & 82.9 \\
11 & 10.0 & 1050 & 30 & 95 & 20 & 94.8 \\
12 & 10.0 & 1100 & 40 & 85 & 15 & 89.9 \\
13 & 10.5 & 950 & 60 & 95 & 15 & 83.1 \\
14 & 10.5 & 1000 & 50 & 85 & 20 & 87.5 \\
15 & 10.5 & 1050 & 40 & 115 & 5 & 93.2 \\
16 & 10.5 & 1100 & 30 & 105 & 10 & 84.7 \\
\hline
\end{tabular}

Based on the results of the above statistics.Using the orthogonal test, the results are as follows:

\begin{tabular}{cccccc} 
& $\mathrm{A}$ & $\mathrm{B}$ & $\mathrm{C}$ & $\mathrm{D}$ & $\mathrm{E}$ \\
\hline K1 & 339.2 & 321.3 & 341.4 & 354.1 & 346.9 \\
K2 & 353.9 & 340.4 & 350.1 & 356.8 & 348.8 \\
K3 & 346.9 & 377.9 & 350.8 & 339.7 & 348.1 \\
K4 & 348.5 & 348.9 & 346.2 & 337.9 & 344.7 \\
R & 14.7 & 56.6 & 9.4 & 18.9 & 4.1 \\
$\begin{array}{c}\text { Excellent } \\
\text { level }\end{array}$ & 9.5 & 1050 & 50 & 95 & 10 \\
\hline
\end{tabular}

The analysis of variance is shown in Table 2.4 
Table 2.4

\begin{tabular}{|c|c|c|c|c|c|c|}
\hline $\begin{array}{c}\text { Source } \\
\text { of } \\
\text { variance }\end{array}$ & $\begin{array}{c}\text { Sum of } \\
\text { squares }\end{array}$ & $\begin{array}{c}\text { degree } \\
\text { of } \\
\text { freedom }\end{array}$ & $\begin{array}{c}\text { Mean } \\
\text { variance }\end{array}$ & $\begin{array}{c}\text { value of } \\
\text { F }\end{array}$ & Fa & Significant \\
\hline factor A & 27.6619 & 3 & 9.2206 & 11.4217 & $9.2766 ; 29.4567$ & Remarkable \\
\hline factor B & 415.6019 & 3 & 138.5340 & 171.6034 & $9.2766 ; 29.4567$ & $\begin{array}{c}\text { highly } \\
\text { significant }\end{array}$ \\
\hline factor C & 13.9969 & 3 & 4.6656 & 5.7794 & $9.2766 ; 29.4567$ & \\
\hline factor D & 70.6219 & 3 & 23.5406 & 29.1600 & $9.2766 ; 29.4567$ & Remarkable \\
\hline factor E & 2.4219 & 3 & 0.8073 & 1.0000 & $9.2766 ; 29.4567$ & \\
\hline error & 2.4219 & 3 & 0.8073 & & & \\
\hline sum & 530.3044 & 15 & & & & \\
\hline
\end{tabular}

In order to be more intuitive, the horizontal coordinate is used as the factor, the calculated value of $\mathrm{K}$ is used as the vertical coordinate to make the trend chart of the relationship between indicators and factors. These representing factors of electrolytic voltage (A), electrolytic temperature (B), reaction time $(\mathrm{C})$ and polar distance $(\mathrm{D})$, feeding frequency $(\mathrm{E})$ the trend chart is as follows.

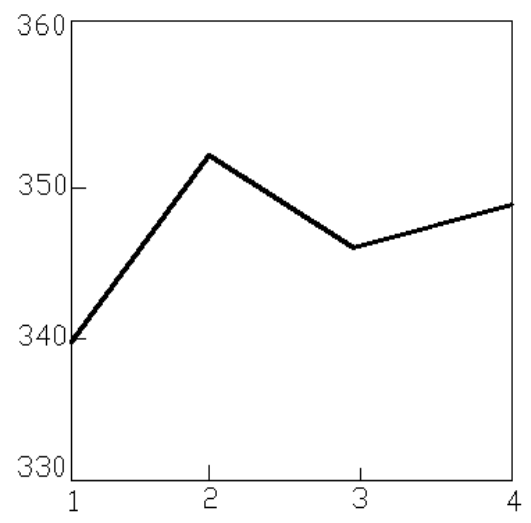

Figure 2 factor $\mathrm{A}$

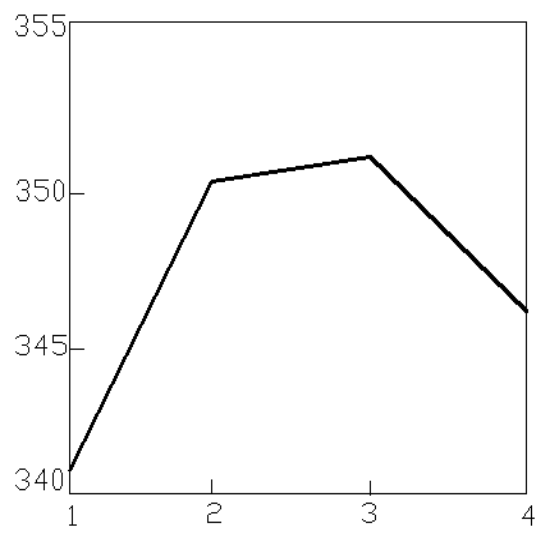

Figure 4 factor $\mathrm{C}$

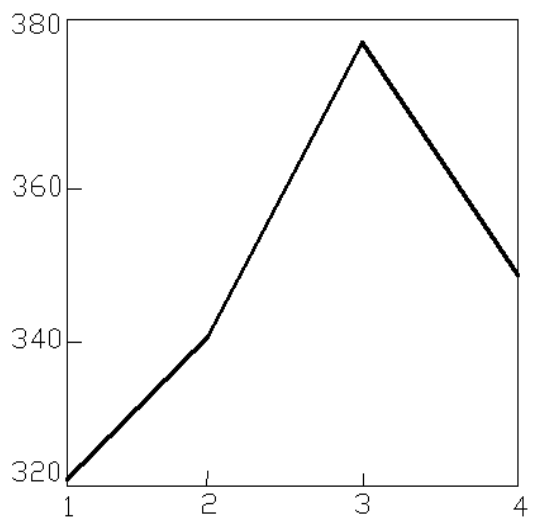

Figure 3 factor $\mathrm{B}$

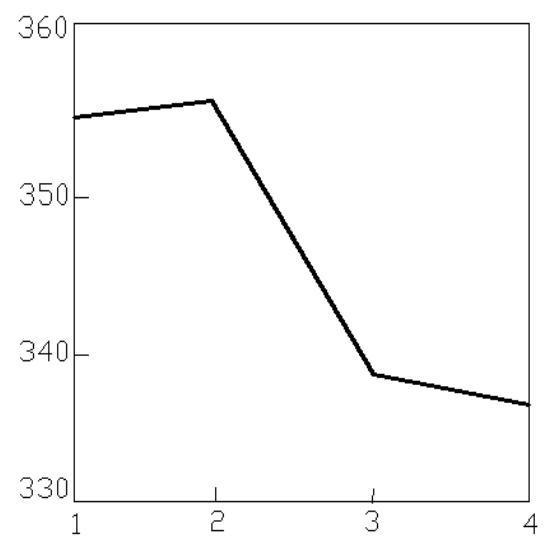

Figure 5 factor D 


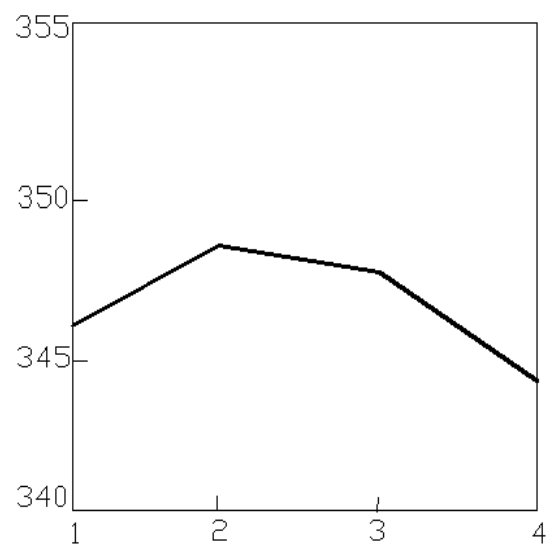

\subsection{Result analysis}

Figure 6 factor $\mathrm{E}$

From the results of the above range and variance analysis, Carbon content (qualified rate) as evaluation index, Based on the calculated $R$ value, The factors of praseodymium neodymium alloy production qualification rate of the final order of influence: $B>D>A>C>E$, According to the factors of the horizontal trend chart can be more intuitive to determine the level of the best factors: $\mathrm{B}_{3} \mathrm{D} 2 \mathrm{~A} 2 \mathrm{C} 3 \mathrm{E} 2$, The results of analysis of variance showed that, Factor $\mathrm{C}$ had no significant effect on the results of production, Factors $\mathrm{A}, \mathrm{B}$ and $\mathrm{D}$ had significant influence on the production results, Among these factors, the effect of $\mathrm{B}$ on the results was highly significant, In order to improve the production efficiency, save production time, Combined with visual analysis results, We finally determine the optimal process parameters for $\mathrm{B} 3 \mathrm{D} 2 \mathrm{~A} 2 \mathrm{C} 2 \mathrm{E} 2$.

\section{Verification test}

Based on the results of the above analysis, we choose B3D2A2C3E2、B3D2A2C2E2 two groups of process parameters combination, 3 parallel experiments were made for each group, The average eligible rates of the two groups were $98.7 \%$ and $98.1 \%$, respectively, Two groups of tests have higher pass rate and almost no big difference, But from the improvement of production efficiency, shorten the production time, $\mathrm{B}_{3} \mathrm{D} 2 \mathrm{~A} 2 \mathrm{C}_{2} \mathrm{E} 2$ combination can bring more economic benefits to enterprises.

\section{Conclusion}

There is no uniform standard for electrolytic production in the factory, This experiment uses the scientific data processing method. To establish a multi factor and multi level orthogonal experiment to find out the best level of the production process parameters. Practice proves that this method is correct and effective. These can provide reference for the enterprise's production operations.

\section{Reference}

[1] Liu Lijing. Importance of rare earth and its application [J] . Inner Mongolia petrochemical industry, 2004, 3:36-37.

[2] Shi Fu. Research status and development trend of rare earth electrolysis cell [J]. Chinese Journal of rare earth science, 2007, 5:7-8.

[3] Zhou Aiguo, Chen Yanxin, Peng Shaohua, silicon of fused salt electrolysis process for preparation of praseodymium neodymium alloy influence [J]. China tungsten industry, 2012, 27 (2): 44-46.

[4] Wu Yongfu, Liu Zhongxing, Ren Yongfeng et al. Simulation and Simulation of the electric field of the four anode high efficiency and energy saving sodium reduction cell [J]. Journal of Inner 
Mongolia University of Science and Technology, 2008, 27 (1):90-93.

[5] Chen Kui. Experimental design and analysis [M] . Beijing: Tsinghua University press, 1996

[6] HeWei Xue Weidong, Tang Bin. Optimization experiment design method and data analysis, chemical industry publishing house, 2012

[7] Zhou Yuzhu. Matrix analysis method of orthogonal test design [J]. mathematics practice and cognition, 2009, (02): 202-207. 